\title{
Environmental Awareness: An Advocacy of The Mahabharat
}

Narayan Bahadur Magar

Principal, Mega International College, Lalitpur, Nepal

The sublimation or the deterioration of the Earth depends on how the humans act over the natural world. The Mahabharata, an ancient Sanskrit literary text, reveals a way to the modern human as to treat with the natural phenomena. The degraded environment of the present more or less depends on how the human takes the natural world. This paper uses the Mahabharata, an English translation by Kisari Mohan Ganguli to analyze the text from ecological perspective. The researcher envisions the human relationship with the natural world in the epic through the concept of spiritual ecology.

Spiritual ecologist Ken Wilber finds the cause of present environmental crisis due to a fractured worldview (14) such as mind and body, subject and object, culture and nature, spirit and matter, human and nonhuman and so on. The modern people have ignored one in the selection of another or put less importance to one and more to another. Such dualistic view has neglected spirituality whereas material things have got priority. Wilber opines that the dualistic and hierarchical concept is destructive from ecological point of view. He blames the concept, which separates the humans from nonhuman and elevates the humans above of others, to be erroneous. He asserts that there is equal role of all the aspects in the web of patterns and relationship that help to constitute the very nature of life and Earth and cosmos (15).

The natural world was sacred and venerable in the past when the presence of spirituality in the natural phenomena was accepted. The natural world was revered as godly image with the faith of having soul in them. Though modern people with materialistic concept see the natural world from anthropocentric view, the spiritual ecologists accept the presence of soul in the nature. Bill Plotkin terms the soul of the world to be anima mundi (161). John Stanley and David Loy accuse the modern human for living in the world of left hemisphere that has replaced anima mundi and suggests returning to the right hemisphere. "We now live in the world the left hemisphere has built, replacing the ancient Soul of the World (Anima Mundi) with its own mechanistic model. The right hemisphere's concern for empathic relationship and a broader vision has been marginalized" (Stanley 44).

Some ecologists believe that the ancient spiritual faith and practice over the natural world is still surviving among indigenous traditions and ancient literature. But, the modern humans have forgotten that they have been connected with the natural world physically and spiritually for a healthy survival of all. 
We have lost and entirely forgotten any spiritual relationship to life and the planet, a central reality to other cultures for millennia. Where for indigenous peoples the world was a sacred, interconnected living whole that cares for us and for which we in turn need to care-our Mother the Earth-for our Western culture it became something to exploit. (Vaughan-Lee 206)

Tucker says that the modern people have deserted the teachings of the creator and the Mother Earth to have responsibilities toward the lands from where they sprung and have survived. He suggests reviving the ancient reverential practices and adopting the way of living of the indigenous place based societies (84) in order to protect and reaffirm the human relationship with the sacred natural world. Satish Kumar opines that ancient Hindu Sanskrit text, the Bhagvad Gita (an important portion of the Mahabharata) to be holistic in terms of the relationship among ecology, spirituality and humanity. He writes,

However, an ancient Hindu text, the Bhagavad Gita, contains a trinity which in my view is holistic, and inclusive of ecology, spirituality and humanity. That trinity in Sanskrit is yagna, tapas and dana. Yagna relates to human/nature relationships, tapa relates to human/divine relationships and dana relates to human/human relationships. I have translated this trinity into English as Soil, Soul and Society. (117)

He interprets trinity of Sanskrit yagna, dana and tapas with the modern essentials i.e. ecology, spirituality and humanity for wellbeing of all on the earth. He says yagna connects the human with the nature, tapa combines the human with the God and dana relates one human with another. The trinity relationship is indispensable from ecological point of view.

The Mahabharata preserves spiritual remedies for healing the Earth. It conveys the message for conservation of ecology and environment. Mishra writes about Hindu scriptures including the Mahabharata as, "The scriptures have enormous indication underlining the central thought of environment preservation: All is God, all is divine, all is to be treated with reverence and respect, and all is sacred" (581). UN General Assembly has also acknowledged Hindu philosophy to be ecofriendly. The report presented at the session in 2010 states that the Sanskrit literature including the Mahabharata gives importance for the relationship between the human and nature. They contain the earliest messages on ecological balance with the ethical treatment of the human beings with the natural world. There should be harmonious relationship with the nature by recognizing the presence of divinity in each and every natural element (5).

The Mahabharata mentions that every element of the nature including the human being is composed of two attributes i.e. prakrti and purusa. It states that prakrti and purusa are without beginning and end. They are undecaying and incomprehensible ((Vol. X, Santi 
Parva (Part III), CCCXV, 41). Here, prakrti refers to physical part whereas purusa is spiritual aspect of an existent in the natural world. Every living and non-living, human and non-human object of the earth contains soul (purusa) for their existence. Nothing can exist without the amalgamation of the purusa with the prakrti. Larson asserts this maxim as, "Without this association or proximity of prakrti and purusa, there would be no worldly existence or human experience" (12). Santi Parva of the epic contains detail discussion of prakrti and purusa. It mentions that prakrti is inanimate and unintelligent but it cannot create thing without the combination with the purusa. Similarly, though pusura is intelligent, it cannot come in form unless it resides with the prakrti (Vol. X, Santi Parva (Part III), CCCXV, 41). Therefore, Larson compares prakrti and purusa with a lame man and a blind man who can move ahead until they get united helping each other for moving (13).The changes and transformations in the natural world is due to combination and separation of prakrti and purusa.

The Mahabharata argues the purusa to be Supreme Soul (Brahman). It says Supreme Soul is one, eternal, indivisible, unperishable, incomprehensible and without decay and death. In Santi Parva it mentions the purusa as, “...the Supreme Soul which is One, ...which is Immutable and Infinite and Pure and without defect, who is Eternal purusa,...everlasting,... Indivisible,... without decay and death, ...who transcends diminution, and...Immutable Brahman" (Vol. X, Santi Parva (Part III), CCCXVII, 45). When Supreme Soul amalgamates with the prakrti for creation, then it is known as Jiva Soul or Jivatman (Individual Soul). The Sankhyas and Yogins regard the Jiva-soul and the Supreme Soul to be one and the same (Vol. X, Santi Parva (Part III), CCCXIX, 51). Every creation is the creation of the Supreme Soul (God) with certain purpose, value and place in the natural world to operate ecocystem. In this sense, nothing is useless and of less importance in the universe.

Vyasa, the author of the epic assures that the Earth, Sky and Oceans are created by the Supreme Soul (God). Moreover, every phenomenon of the universe such as day and night, living and non-living things, mobile and immobile, deities and human, good and evil, light and dark, physical and emotional things are the creations of the Supreme Soul to operate the universe under cosmic order $\left(R t a^{l}\right)$. Vyasa presents Krishna as the embodiment of the Supreme Soul in the epic. He states that all the natural worlds are the creation of Krishna (Supreme Soul), “...

Form and light, sound and sky, wind and touch, taste and water, scent and earth, time, Brahma himself, the Vedas, the Brahmanas and all these mobile objects, have sprung from thee" (Vol. VI, Drona Parva, CCI, 482).

The Supreme Soul has wisely set cosmic code (Rta) in order to operate the universe in rhythm defending and depending to each other in the natural world. The epic states that the Supreme Soul has deployed different deities for executing and supervising the cosmic 
order apart from His direct supervision. The Sky, the Earth and the Water have got their deities for supervision and protection: Indra as Lord of Sky, Goddess Earth of land and Lord Varuna for Water. These deities are responsible for the protection and wellbeing of the dwellers on them.

It is the duty of Lord Indra to keep the Sky safe and peaceful under cosmic order. Varuna has responsibility to protect the creatures of the water and Goddess Earth pours her love, affection and protection of the creatures of the land.

When the deities of three worlds are unable to maintain peace and order due to violation of cosmic order, then they seek help from the Supreme Soul. If sins take place in different forms: killing, injuring, encroachment, destruction, pollution and violation, then Supreme Soul takes initiation to cleanse the sins. Vyasa states that the Earth is also under kind supervision of the Supreme Soul. Whenever sins and cruelties become unbearable on the earth, then the Supreme God upholds to provide justice to the innocents and maintain dharma $^{2}$ on the land. Vyasa writes, "The Supreme deity Narayana is the Lord of all the foremost of Rishis ${ }^{3}$, and of the three worlds. He is the upholder of Earth herself of vast proportions" (Vol. X, Santi Parva (Part III), CCCXLVII, 179).

Rishi Lomasa narrates a story of Krita Yuga (Krita Age) to Yudhishthira how Supreme Soul supported and protected the Earth from collapse. At a time, the Earth had to bear cosmic disorder due to increment of violations, sins and cruelties. The population of humans and creatures was increasing continuously. But, there was no death and decay. The Earth could not bear and hold the weight. As a result, the Earth starts sinking down in the nether land gradually. The epic mentions this as, "Earth oppressed with the excessive burden, sank down for a hundred yojanas" (Vol. III, Vana Parva (Part II), CXLII, 292). Then the Earth seeks help from Vishnu (Supreme Soul) in the following words,

It is by thy favour, $\mathrm{O}$ possessor of the six attributes, that I had been able to remain so long in my position. But I have been overcome with burden and I cannot hold myself any longer. It behoveth thee, $\mathrm{O}$ adorable one, to relieve this load of mine. I have sought thy protection. O lord; and do thou, therefore, extend unto me thy favour. (Vol. III, Vana Parva (Part II), CXLII, 292)

It is the ultimate responsibility of the Supreme Lord to maintain cosmic order. Therefore, Vishnu helps in it by addressing the Earth as the bearer of all treasures. Supreme Soul (Vishnu) speaks to the Earth with the words, "Thou need not fear, O afflicted Earth, the bearer of all treasures. I shall act so that thou mayst be made light" (Vol. III, Vana Parva (Part II), CXLI, 292).

The Mahabharata suggests the human being to abide by cosmic order by accepting and respecting the existence of all the natural phenomena from their own cosmic position. 
To be functioning through natural order by limiting the hurts and encroachment is dharma. The epic mentions different kinds of dharma. But, every individual human should follow at least universal dharma (being responsible to the natural world) and personal dharma (keeping self control). When universal and personal dharma is violated, it invites crisis and destruction in the world. Wilmot writes,

In the 'Mahabharata,' Dharma is in crisis. This is its central preoccupation, for a world whose ultimate order and balance are threatened is a world that will fall apart. The 'Mahabharata' portrays this decay of Dharma, this fragmentation of a fragile order, and the chaos and destruction that result.

The righteousness should be maintained while treating with the natural world for preserving dharma. One should not injure any creature physically or mentally for his/her self pleasure and benefit. Vyasa states that if one destroys dharma, the same dharma destroys him/her (Vol. I, Adi Parva, XLI, 90). One should present himself/herself in perfect friendliness towards all in order to maintain dharma (Vol. X, Santi Parva (Part III), CCCXXX, 99).

Yudhishthira establishes himself as a dharmic character throughout the epic. In the epic, Bhishma explains about Kshatriya dharma to Yudhishthira. He teaches Yudhishthira that it is the highest duty of the Kshatriya to protect all the creatures of the world (Vol. VIII, Santi Parva (Part I), CXX, 257). Yudhishthira is well-informed that one can get complete happiness in life if he/she does not injure any creature in thought, word, or deed. He keeps himself away from injustice and adharma. He attempts to preserve dharma by always speaking truth and not hurting to anyone. The animals, other creatures and human beings all are equal for him.

Yudhishthira shows his highest example of dharmic character at the last part of the epic. Pandavas take their journey to the Himalaya after Yudhishthira's rule for thirty six years in Hastinapur aftermath the war. All his brothers and Draupadi collapse on the way during their journey of Himalaya. Yudhishthira and a dog, which has been following them along their way, reach to the top of the Himalaya. Then, God Indra comes to take Yudhishthira with chariot and asks him to climb the ladder to the heaven. Indra asks Yudhishthira not to take the dog with him as he cannot go to the heaven with it. Then Yudhishthira refuses to go to the heaven if he cannot take the dog with him since the dog has been his close friend throughout his journey. He does not see any difference between himself and the dog (Vol. XII, Mahaprasthanika Parva, Sec. III, 5). During exile, he decides to leave Kamyak forest and stop hunting animals in the jungle when some deer, in his dream, render their plight and request Yudhishthira to stop killing them (Vol. III, Vana Parva (Part II), CCLVI, 507). Apart from this, the epic treats the animals, vegetation and water bodies with profound veneration in order to maintain dharma and cosmic order. 
The epic treats all the water bodies of the earth as the tributaries of the River Ganga which is known as the embodiment of goddess Ganga descended from the heaven for sustaining and wellbeing of the lives on the earth (Vol. II, Vana Parva (Part I), CIX, 235). Therefore, all the sources of water and water bodies are supposed to be holy and worth worshipping as pilgrimages. The Pandavas take information of different tirthas ${ }^{4}$ and holy rivers worth visiting in order to purify and get blessings. Among the rishis, rishi Pulastya states that there exist many tirthas on the Earth and the firmament; they can be rivers, lakes, smaller lakes, springs, tanks, large and small, and spots. They all are sacred and related to particular gods. Among the tirthas, Sannihati is the most important one as all the small and big tirthas mingle at Sannihati together. Therefore, one can get purified and go to the heaven after bathing and drinking of its water (Vol. II, Vana Parva (Part I) 182). The epic mentions that even evil characters (Rakshasas) can purify and cast off their bodies to be able to go to heaven when they worship and bath with the water from the Saraswati river (Vol. VII, Salya Parva, XLIII, 119).

Plants and vegetation are equally revered and treated venerably in the epic. The trees and forests are supposed to be the abodes of the gods and goddesses. The epic persuades to plant and preserve trees in order to get heavenly blessings. Since gods and goddesses prefer to dwell in the trees and forests, one needs to plant trees to make them happy. When one plants trees and tends them like his/her own children, then the very plants can rescue him/her like children rescuing their parents (Vol. XI, Anusasana Parva (Part II), LVIII, 60). The planters of the trees can achieve fame both in this life and after life (Vol. XI, Anusasana Parva (Part II), LVIII, 59).

The animals and birds are worth mentioning to show ecologically respectable in the Mahabharata. The epic teaches to love and respect all the creatures equally. The human being, as a conscious and intellectual one, should abandon cruelty while treating to the creatures of the world. Rather, they have to treat them as the parents care for their children with love (Vol. XI, Anusasana Parva (Part II), CXVI, 244). The epic warns the human being not to hurt and kill harmless creatures since nobody can escape from punishment under cosmic code if they involve in harming creatures (Vol. XI, Anusasana Parva (Part II), CXIII, 235). It states that a ruler/ leader cannot be good ruler/leader if he/she cannot treat all the creatures of the world equal to the humans. A virtuous ruler/leader can be beloved even of the creatures (Vol. VIII, Santi Parva (Part I), CII, 222).

The epic discourages sacrifice of the animals and birds whether it is for meat or for worshipping the god. The epic mentions that the meat of animals is like the flesh of one's son. Therefore, he/she, who kills animals for meat, is like killing his/her own children (Vol. XI, Anusasana Parva (Part II), CXIV, 236). Moreover, it blames six persons to be sinner when an animal is slaughtered in a slaughter house. The sinners involved in killing animals for meat are: one who eats, one who cooks, one who purchases, one who helps while killing, one who kills and one who gives permission for killing (Vol. XI, Anusasana Parva (Part II), CXV, 239). 
In the same way, the epic clarifies that sacrificing animal on altar is also an act of committing sin. After the Mahabharata war, Yudhishthira organizes Aswamedha Parva to sacrifice thousands of animals and birds available on the earth to make the god happy for the eternal peace of the departed souls during the war. The sacrifice of the creatures is duly performed. But, aftermath of the sacrifices, God appears at the sacrificial altar in the form of a mongoose and vilifies the sacrifices. The mongoose addresses that the sacrifice was not as effective as a gift of a prastha $a^{5}$ of powdered barley offered by a poor Brahmana during his Unccha ${ }^{6}$ vow (Vol. XII, Aswamedha Parva, XC, 155). The mongoose suggests that a handful of water or a leaf or a flower satisfies him far better than those killings of animals and birds if it is offered with pure heart. Krishna also speaks this reality by addressing to Arjuna as, "They who offer me with reverence, leaf, flower, fruit, water-that offered with reverence, I accept from him whose self is pure" (Vol. V, Bhishma Parva, XXXIII, 75).

The Mahabharata is ringing a bell of environmental awareness by inculcating the humans how to treat with the natural world. It bolsters the principles of spiritual ecology to revere and respect the natural phenomena. The epic reassures the presence of Supreme Soul in the universe. The presence of the Supreme Soul is to maintain peace and prosperity in the natural world with the operation of the cosmic code. It also states that every existent in the universe contains individual soul (Jivatman) derived from Supreme Soul. It teaches to maintain dharma by respecting the existence of all the elements of the nature. The epic discourages all kinds of violation, injuries and sins in the natural world.

\section{Works Cited}

Ganguli, Kisari Mohan. Trans. The Mahabharata of Krishna-DwaipayanaVyasa. New Delhi:

MunshiramManoharlal Publishers, 2007. Print.

Kumar, Satish. "Three Dimensions of Ecology: Soil, Soul and Society.” Spiritual Ecology:

The Cry of the Earth. Ed. Llewellyn Vaughan-Lee. California: The Golden Sufi Center, 2013. Print.

Larson, Gerald James. Classical Samkhya: An Interpretation of Its History and Meaning. Delhi:

MotilalBanarsidass Publishers, 1979.Prinit.

Plotkin, Bill. "Care of the Soul of the World." Spiritual Ecology: The Cry of the Earth. Ed.

Llewellyn Vaughan-Lee. California: The Golden Sufi Center, 2013Vaughan-Lee, Llewellyn. "The Call of the Earth." Spiritual Ecology: The Cry of the Earth. Ed.

Llewellyn Vaughan-Lee. California: The Golden Sufi Center, 2013. Print.

Stanley, John \& David Loy. "At the Edge of the Roof: The Evolutionary Crisis of the Human 
Spirit." Spiritual Ecology: The Cry of the Earth. Ed. Llewellyn Vaughan-Lee. California: The Golden Sufi Center, 2013. Print.

Sullivan, Bruce M. Historical Dictionary of Hinduism. London: Scarecrow Press, 1997. Print.

Tucker, Mary Evelyn \& Brian Thomas Swlmme. "The Next Transition: The Evolution of Humanity's Role in the Universe." Spiritual Ecology: The Cry of the Earth. Ed. Llewellyn Vaughan-Lee. California: The Golden Sufi Center, 2013. Print.

UN General Assembly, Sixty-fifth Session, Document A/65/314. "Sustainable Development: Harmony with Nature", Report of the Secretary-General, Issued: 19 Aug. 2010. Para 21. Web. November 2015

Wilber, Ken. Sex, Ecology, Spirituality: The Spirit of Evolution. Colorado: Shambhala, 1995.

Print.

Wilmot, Paul. Trans. Mahabharata Book Two: The Great Hall. New York: NYUP, JJC Foundation, 2006. Print. 